\title{
Untangling the Complexities of Successful Tendering Practices: Exploring the Factors Leading to Bidding Success from a General Contractor's Perspective
}

\author{
Baris Bekdik ${ }^{1 *}$ and Christian Thuesen ${ }^{2}$
}

\begin{abstract}
The purpose of this paper is to explore the complexity of tendering practices from a contractor perspective by investigating the conditions that lead to successful bid results. To do this, the Qualitative Comparative Analysis (QCA) method is used to describe combinations of conditions and their results. Empirical material collected through data mining of previously completed building projects in Denmark (quantitative data) is supported by data obtained from project managers of the same general contractor company (qualitative data) in order to holistically describe the combination of conditions that has resulted in particular tender results. The major finding of the analysis is a solution set explaining the path leading to the winning of project contracts; previous work experience between the client and general contractor, together with either previous work experience between the architect and general contractor for design-bid-build projects, or senior project manager involvement on the contractor's side in design-build projects. The analysis illustrates how contracting companies whose existence is highly dependent on winning new contracts can learn from patterns abstracted from previous projects. The results will contribute to the development of more predictable project organizations and might thereby be used to help construction organizations allocate valuable resources during the bidding phase in the best way possible.
\end{abstract}

\section{Keywords}

Organizational repetition, project organization, QCA, successful bid, tender practices

${ }^{1}$ MTHøjgaard A/S, Søborg, Denmark, email: barbe@ @dtudk, bbe@ @mth.dk (corresponding author)

${ }^{2}$ Management Engineering Department, Technical University of Denmark, email: chth@ dtu.dk 


\section{Introduction}

Construction companies are typical examples of project-based organizations (Chinowsky, 2011) that work in dynamic environments and in shortterm collaboration patterns. After construction projects are terminated, the project teams are usually dissolved while a core team remains, depending on the company's size, capacity and future projects in the pipeline (Bower, 2003). Because they operate in a highly volatile environment, construction companies must adjust their organization according to the market for future projects. Moreover, as all projects will eventually be completed, these types of companies are highly dependent on their ability to win new contracts in order to keep the business running.

It is a well-recognized fact among academics and practitioners that decisions made at the beginning of a project have the most significant consequences for the success or failure of the project (Winch et al., 1998). One of the main decisions affecting the overall project is how to bring the right companies together. Given the importance of this issue, tender practices have been subject to a considerable amount of primary research from a client perspective, covering topics such as contractor prequalification (Nieto-Morote and Ruz-Vila, 2012) and decision-making during the project tender phase (e.g., Hatush and Skitmore, 1997; Diekmann, 1981).

However, when it comes to investigating the factors leading to contract gain or loss from the contractor's perspective, the literature remains limited (Fayek, 1998; Mochtar and Arditi, 2001). Fayek (1998) introduces more than 90 factors that may help to build a bidding strategy where Mochtar and Arditi (2001) try to reveal the existing pricing strategies among US contractors.

The purpose of the present paper is to provide a mechanism that will enable successful tenders by general contractors. In this case study, which takes as its focus the tendering practices of a Danish general contractor, the patterns leading to successful bids are studied from the contractor's perspective. The research question is therefore as follows: What combinations of factors lead to successful tender results for a bidder (general contractor) in construction projects?

Untangling complexity requires understanding the various factors and the interaction between them in different settings, such as organizations, people and culture (Geraldi and Adlbrecht, 2007). QCA has proven to be a promising method for studying the complexity of institutional practices (Thomas et al., 2014). QCA was chosen as the method of analysis because it allows researchers to uncover different combinations of conditions that lead to a particular outcome (Jordan et al., 2011). The QCA method has appeared recently in built environment studies to analyse different areas, such as sustainability (Kaminsky et al., 2014), disaster recovery, with Hurricane Katrina as the focus of analysis (Jordan et al., 2014), and contract elements that lead to success in public-private partnership (PPP) projects (Gross and Garvin, 2011).

The premise for using QCA is that it provides an in-depth understanding of the research results by identifying interesting outcomes and relevant independent variables. As such, QCA is always based on a rigorous mapping of the current state of the art, combining literature reviews and empirical investigations (Ragin, 1987; Rihoux and De Meur, 2009). Hence, this paper opens with a literature review of tendering practices, followed by a detailed introduction to the applied methodology, QCA. Subsequently, the analysis of the selected cases and conditions, including previous work experience between different parties, such as client, architect, contractor and general contractor, as well as project attributes like project type, delivery system, seniority levels of the contractor tender manager and the project manager (PM), are investigated. Finally, a solution set leading to a successful contractor bid is presented in the results, discussion and conclusion sections. 


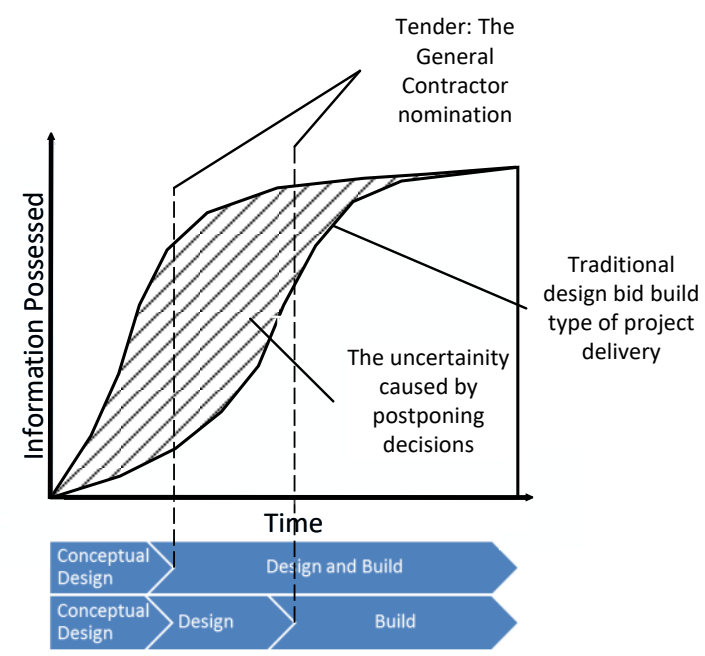

Figure 1. The uncertainty related to the project lifecycle in different project delivery systems (Inspired by Winch et al., 1998)

\section{Literature Review}

As the purpose of this paper is to provide a sort of 'contractor's guide to the tendering process,' it is clear that a wide variety of aspects must be considered (Bagies and Fortune, 2006). Becker (2004) addresses the circumstance in which uncertainty in decision-making is problematic because the likelihood of each outcome from a set of possible specific outcomes is initially unknown, as is the case in the early project phases (see Figure 1). In handling such uncertainty, it is important to understand the tender phase and contractor selection.

What does the construction management literature say about the key factors in the tendering phase and what can it teach us about how to identify the elements of a successful bid? Studies of construction management in general and on tendering practices in particular tend to focus on the complexity, uncertainty and high degree of subjectivity complicating the decision-making process. Here, we provide a review of the "complexity problem," as described by a variety of authors, along with some recurring themes across studies that appear to be important to a successful tender.
Subjectivity is the most challenging attribute of tender process encountered by researchers and practitioners due to a diverse range of prequalification criteria (see Table 1), as well as variability in the same contractor's ratings when different clients assess them differently according to their own perceptions. Tenders are multifaceted and involve many engineers and managers who must work as a team, share information and deal with the interface problems that arise between the various responsible subsystem engineers (Bernold and AbouRizk, 2010). The choice of eligible bidders is made according to prequalification criteria, the contractors' attributes and the client's judgement. Despite the effort made by researchers, contractor prequalification remains largely an art, where subjective judgment based on the decision maker's experience, becomes an essential part of the contractor shortlisting practice (Nguyen, 1985).

Some tools that have been developed to better track and control the uncertainties are so-called multiattribute utility functions, which list the criteria describing the decision-maker's preferences (Diekmann, 1981; Hatush and Skitmore, 1998). Based on these functions, increasingly advanced tools for contractor selection have been developed (e.g. Cheng and Li, 2004). However, they all reflect the decision-makers, i.e. the client's, perspective and not the bidder's.

There are uncertainties in the early project phases as seen in Figure 1, inspired by Winch et al. (1998). The uncertainty dominates the early stages of projects and certainty gradually increases with time and as the project approaches completion. During tender phases, the different organizations and organizational entities come together to share and create information for the first time. Such collaboration is done through traditional contractual arrangements (Cornick and Mather, 1999). Therefore, the tendering phase can be regarded as a critical stage in the realization of projects because of the high uncertainty.

Towards the end of the projects uncertainty decreases but, each new project starts from the bottom with the same uncertainty curve every time. To overcome this project cycler repeating itself, the partnering of two or more parties across projects is mentioned in Egan's (1998) report as a way to 
Table 1. Decisive condition in contractor selection (Nieto-Morote and Ruz-Vila, 2012)

\begin{tabular}{ll}
\hline Criteria & Sub-criteria \\
\hline Technical capacity & 1. Qualification of staff \\
& 2. Experience of staff \\
& 3. Innovate method \\
Experience & 1. Type and equipment \\
& 2. Size of past project completed \\
& 3. Number of projects completed \\
& 1. Experience in local area \\
Management ability & 2. Organisational culture \\
& 3. Quality pont knowledge \\
Past Performance & 1. Quality level of projects performance \\
& 2. Projects completed on time \\
Financial stability & 1. Projects completed on budget \\
& 1. Financial soundness \\
Occupational health and safety & 3. Liquidity \\
& 1. Management safety accountability \\
& 2. Safety performance
\end{tabular}

resolve disputes as well as to improve performance and share the gains. Therefore, Winch et al. and Egan's arguments support previous work experience between project participants as an important condition for achieving project success. As such, the previous work experience between the general contractor and the client was chosen as an initial condition for this study. As will be elaborated in the analysis section, based on case knowledge, the previous work experience between the general contractor and other parties such as architects and consultants was also added as a condition leading to either winning or losing the tenders.

Stability provides safety in order to achieve the targeted results and increases predictability (Langlois, 1992; Tyre and Orlikowski, 1996). In the construction process, the different parties develop certain working habits and practices that create a bound between them (Marshall, 2014). Moreover, as mentioned by Nelson (1994), whenever there is a change in the participants, understandings or contracts, the mode of executing a particular task needs to be identified and adjusted. This always has an additional cost aspect.

In situations of uncertainty, already-known solutions have an important effect on the way decision makers - in this case, the clients - make their choices (Gersick and Hackman, 1990; Langlois and Everett, 1994; Becker, 2004). A recent case study emphasized that collaboration and trust are primarily needed in projects where uncertainty is high, and that relational requirements are essential in trust-based collaborations (Dewulf and Kadefors, 2012). Taking all these arguments into consideration previous contract and collaboration between the general contractor, client, architect and consultant appear to be important factors affecting the result of the tender practice.

Taking the uncertainty in the projects or, more precisely, in the tender phases, into consideration, the importance of the people involved in the process becomes apparent. Müller and Turner (2007) have been studying the importance of the project leader and his/her leadership style on project success, a topic that has been relatively under-researched. The leadership style, competence and seniority of the PM are success factors for projects and that different styles are appropriate for different types of projects (Müller and Turner, 2007). The PM's role is even more remarkable during the tender phase, as all of his or her previous experience and professional network are utilized to shape the final bid.

Recalling the research question - What combinations of factors lead to successful tender results for the bidder? - the literature covered above has identified the following factors: previous work experience between parties such as client and general contractor, the contractor tender manager and PM's seniority. In the following section, factors observed across projects that lead to contract gains or losses will be investigated holistically by means of the Qualitative Comparative Analysis (QCA).

\section{Research Design and Method}

In order to explore tendering practices, this study applies Qualitative Comparative Analysis (QCA). QCA is a relatively new approach, first propounded by sociologist Charles Ragin in 1987, whose principles have since been applied extensively, primarily in the fields of sociology (Rihoux, 2006) and political science (Ragin, 1987), but also in management, economics and engineering (e.g. Jordan et al., 2011), for the study of complex phenomena. QCA has recently been introduced for the study of various construction practices, such as PPP (Gross, 2011), building information modeling 
(BIM) (Homayouni et al., 2011) and a school sanitation project in Bangladesh (Chatterley et al., 2014).

Different available approaches make the study of project organization and management a matter of choosing the proper method. One can use either (1) a large amount of quantitative data and welldefined hypothesis testing or (2) qualitative data and more explorative research questions. In contrast to working with quantitative data, where the focus is on numbers and statistical correlations without looking at the individual project participants, a growing amount of research has been focused on understanding project organization and management as contextual practices. This approach was initially driven by the Scandinavian school of research on project management and temporary organizing (Morris, 2013), which focuses on the narratives of individual persons. As the type of the registered data from construction projects is rarely sufficient for statistical analysis, the Qualitative Comparative Analysis (QCA) method appears to be the middle ground solution that uses the positive aspects of both the quantitative and the qualitative perspective.

QCA allows researchers to identify combinations of different factors in practice (conditions) that lead to a dependent outcome. As illustrated in Figure 2, the research process is highly iterative; during the process, the literature is revisited and additional empirical material is gathered in order to resolve emerging contradictions.

QCA therefore lies somewhere in between quantitative and qualitative research for testing hypotheses, in addition to allowing the researcher to work with small cases compared to using statistical methods. The method is, however, closer to a qualitative method due to its sensitivity to individual cases (Rihoux and De Meur, 2009). This is also mirrored in the highly iterative process, which is to some degree similar to the iterative interpretations made within qualitative studies.

To make the best use of the available data set to describe a solution set with factors leading to particular project tendering outcomes, a crisp-set QCA (csQCA) method was chosen for this study. In contrast to the fuzzy sets that make use of partial memberships such as 0.5 , the crisp set is based on full membership and full non-membership - in other words absences are 0 and presences are 1, in binary notation (Thomas et al., 2014).

csQCA has certain advantages and limitations that one should be aware of. These were identified by Jordan et al. (2011), and are listed in the Table 2.

In the following analysis section, the process illustrated in Figure 2 will be described in detail step-by-step, so that the reader can understand the QCA research method and future researchers can replicate the study with different cases and data sets. Frequencies and descriptive results are presented in the Appendix. In doing so, it is intended for the reader to follow the preliminary results and changes to the data set - before and after - on the way to the final solution.

The results presented in this paper derive from a combination of quantitative and qualitative data. On the one hand, a set of quantitative data was obtained through data mining of the case company database. On the other hand, qualitative data were gathered through semi-structured interviews and

Table 2 Advantages and limitations of csQCA (Jordan et al., 2011)

\begin{tabular}{|c|c|}
\hline Advantages & Limitations \\
\hline $\begin{array}{l}\text { - Ability to work with a smaller set of data } \\
\text { compared to quantitative approaches } \\
\text { - Ability to work with a large number of cases } \\
\text { compared to qualitative approaches } \\
\text { - Easy to understand for the reader } \\
\text { - Transparent } \\
\text { - Replicable }\end{array}$ & $\begin{array}{l}\text { Dichotomization of data: Transformation of data } \\
\text { into a binary notation } \\
\text { - Difficulty in selecting conditions (independent } \\
\text { variables) and cases } \\
\text { - Lack of a temporal dimension }\end{array}$ \\
\hline
\end{tabular}




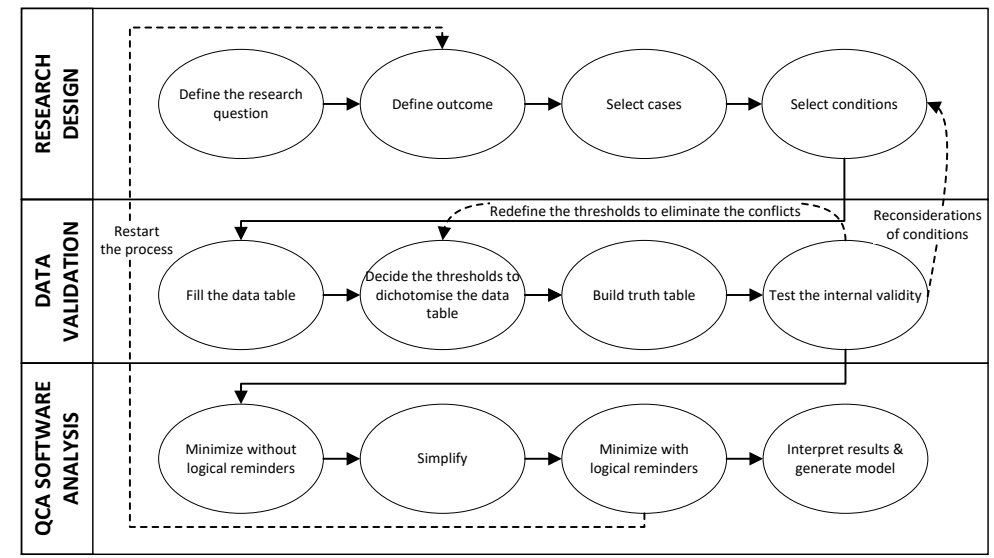

Figure 2. QCA Research Process

phone calls with responsible personnel. The case company is one of the leading general contractors operating in Denmark, with a century-long history behind it. Its annual turnover is about US\$ 1 billion, and its number of employees is about 5,000 . The company's project database consists of all completed and ongoing projects and projects that had an unsuccessful bid. Therefore, many conditions were taken into consideration in the analysis, including project type, contract type, parties involved (clients, architects, consultants etc.), PM, and tender manager. Other factors that helped in selecting the projects to be investigated were contract price, project size, and location. These data were extracted from the database and then combined with the qualitative data. Six of the projects from the database were elaborated through in-depth semi-structured interviews with the PMs who were involved from the initial bidding phase to the commisioning. The interviewees' job titles varied from the tender manager to the senior PM, depending on their level of experience, department and size of the project. The case knowledge was still fresh in the interviewees' memories because only building projects completed within the last five years were chosen for analysis. The interviews took place at the company headquarters and lasted about an hour each. They were recorded and then transcribed. The transcriptions of the interviews, which followed the same structure, were helpful in comparing the projects and gaining case knowledge. A similar number of other projects (cases) from the quantitative dataset were cross checked and elaborated through brief phonecalls and conversations with PMs. All of the project names, together with the names of the responsible parties, have been fully anonymized. A description of a concrete case and the condition selection process will be presented in the next section.

\section{Analysis}

\section{Phase 1 Research Design}

The steps presented in Figure 2 were followed in order to answer the research question presented earlier: What combinations of factors lead to successful tender results for a bidder (general contractor) in construction projects?

\section{Step 1: Outcome Selection}

The initial step of any QCA research method (see Figure 2) is to select the outcome (dependent variable) to be investigated in order to answer the research question. For the purpose of this study, which was to investigate which combination of conditions (independent variables) lead to particular project tender results for a construction company, the outcome was whether the company won or lost the projects. This is represented by 1 for the bids won and 0 for the bids lost.

\section{Step 2: Case Selection}

The second step of QCA is to select cases (see Figure 2). Case selection is critical in QCA, as with other statistical or qualitative methods. The 
selected cases should be diverse enough to ensure explanatory strength in the QCA minimization, while still having comparability (Jordan et al., 2011).

First of all, in order to maintain the comparability aspect, only building projects carried out in Denmark were considered. Secondly, only projects from the last five years were chosen, in order to be able to cross check or elaborate their data through interviews with the PM, still employed at the company. Thirdly, a Pareto analysis was conducted in order to eliminate the relatively less-turnovergenerating projects. All of the 178 projects' tender price amounts were summed. As a result of the Pareto analysis, the 22 building projects accounting for $80 \%$ of the total tender price (in this case, approximately 1 billion Euro in combined turnover) were selected. The reasoning behind the Pareto analysis is that the study should work only with projects that it would make sense to compare. A very large group of projects of all sizes, distributed in very different locations, removes the comparability aspect because different local dynamics are involved in smaller-size projects. However, according to the database and interview results, a similar competitive bidding process was carried out in all large-scale projects. Finally, two cases were excluded from the analysis because the projects were financed by the general contractor itself. The remaining 20 cases are currently in the execution phase or warranty period, which made it possible to contact the PM in order to verify the data or ask more information to judge the case qualitatively.

For the lost-bid cases, in order to have a balance with won-bid cases, the 22 biggest lost and dropped cases according to the total project price within the last five-year period were chosen for analysis. One of the cases was later discarded when it was found out that the project had not been realized at all as a consequence of the landlord's bankruptcy. As a result, 21 lost or dropped building project cases were analysed, with an approximate turnover of 1.5 billion Euro altogether.

Forty-one cases represent only a very small portion of the entire population, if one considers that the total number of cases in the database is about 10,000 . However, the strength of QCA is based on its ability to work with a relatively small amount of data compared to statistical tools (Jordan et al., 2011). Moreover, through the use of QCA, it is intended to draw patterns resulting in particular outcomes, taking each case as equally important in terms of weight rather than identifying correlations between independent and dependent variables (Ragin, 1987). Recently, Boudet et al. (2011) performed a QCA study of 26 infrastructure cases to define the factors leading to conflicts in infrastructure projects in developing countries. This is a typical example of a QCA study working with a middle-range data set.

\section{Step 3: Condition Selection}

The third step of QCA is to select the conditions. For the causal conditions (independent variables), a combination of the comprehensive and inductive approaches was applied: conditions were to some degree selected on the basis of existing theories, but mostly on the basis of case knowledge (Yamasaki and Rihoux, 2009). The literature summarized in Table 1 served as an inspiration in the selection process. However, it was observed that the reviewed literature regarding tender practices only reflects the decision maker's perspective. Therefore, an inductive approach favouring case knowledge and also the bidders' perspective was preferred. The final conditions used in the analysis, together with the description and root of each condition, are presented in Table 3.

When going over the interviews with PMs, in addition to the literature-based client and general contractor work history, some other elements, such as 'previous work experience between the general contractor and other parties' and 'seniority of the PM' emerged as decisive factors. Therefore, previous work collaborations between the general contractor and other parties like client, architect and consultant within the last 10 years were chosen as a condition, with the assumption that people and organizations that have worked together beforehand know each other and have built a relationship of trust. The threshold of 10 years was chosen with the assumption that after 10 years, employees tend to move positions or companies 
and organizations evolve, making new work collaborations similar to newly established ones. process for the collected data, the steps taken from the initial set of conditions to the final conditions presented in Table 3 are described below.

Table 3 Final conditions used in the analysis

\begin{tabular}{|c|c|c|}
\hline Condition & Description and the threshold & $\underline{\text { Source }}$ \\
\hline $\begin{array}{l}\text { Client \& General } \\
\text { Contractor (GC) }\end{array}$ & $\begin{array}{l}\text { Previous collaboration between the general } \\
\text { contractor and client within the last } 10 \text { years: } \\
\text { if it exists take }(1) \text {; if not take }(0)\end{array}$ & $\begin{array}{l}\text { Literature (Becker; Bygballe } \text { et al.; } \\
\text { Egan; Dewulf and Kadefors; Gersick } \\
\text { and Hackman, Langlois; Marshall; } \\
\text { Nelson; Tyre and Orlikowski) \& Case } \\
\text { Knowledge }\end{array}$ \\
\hline Architect \& GC & $\begin{array}{l}\text { Previous collaboration between the general } \\
\text { contractor and architect within the last } 10 \\
\text { years: if it exists take (1); if not take }(0)\end{array}$ & Case Knowledge \\
\hline Consultant \& GC & $\begin{array}{l}\text { Previous collaboration between the general } \\
\text { contractor and consultant within the last } 10 \\
\text { years: if it exists take }(1) \text {; if not take }(0)\end{array}$ & Case Knowledge \\
\hline Client Type & $\begin{array}{l}\text { Private or public: for public clients take }(1) \text {; } \\
\text { for private take }(0)\end{array}$ & Case Knowledge \\
\hline $\begin{array}{l}\text { Project Delivery } \\
\text { System }\end{array}$ & Design \& build projects $(1)$, others $(0)$ & Case Knowledge \\
\hline Project Type & $\begin{array}{l}\text { If residential (1), others (office, hospital, } \\
\text { hotel vs) (0) }\end{array}$ & Case Knowledge \\
\hline $\begin{array}{l}\text { Tender Manager's } \\
\text { Seniority }\end{array}$ & $\begin{array}{l}\text { Tender manager's seniority in the sector: for } \\
15 \text { years or more take }(1) \text {; for less take }(0)\end{array}$ & $\begin{array}{l}\text { Literature (Kog and Loh; Muller and } \\
\text { Turner) \& Case Knowledge }\end{array}$ \\
\hline $\begin{array}{l}\text { Project Manager's } \\
\text { Seniority }\end{array}$ & $\begin{array}{l}\text { Project manager's seniority in the sector: for } \\
15 \text { years or more take }(1) \text {; for less take }(0)\end{array}$ & $\begin{array}{l}\text { Literature (Kog and Loh; Muller and } \\
\text { Turner) \& Case Knowledge }\end{array}$ \\
\hline
\end{tabular}

Furthermore, the threshold of 15 years of experience for the PM and tender manager follows the study by Kog and Loh (2012). According to them, the judgement of managers with less than 15 years of experience differs from that of the more experienced managers. Hence, the views of respondents with less than 15 years' experience in construction are likely to be biased or misleading.

Factors such as 'organizational working history' as well as certain project attributes like 'project delivery system,' 'contract form,' and 'client type' were also consistently mentioned by PMs as conditions having a decisive effect in the bidding process. Therefore, these factors were chosen for the final conditions.

\section{Phase 2 Data Validation}

Table 3 represents only half of the initial conditions. In order to illustrate the calibration
According to Berg-Schlosser and De Meur (2009), there exists no predefined proportion for the number of conditions and cases; thus, the number of combinations and cases should be determined in most applications through a process of trial and error. As an example, for an intermediate-N analysis containing 10 to 40 cases, between 4 and 6-7 conditions can be selected (Berg-Schlosser and De Meur, 2009).

The initial selection of conditions and their thresholds for this QCA study looked like the following:

- Previous collaboration between the general contractor and client within the last 10 years: if it exists take 1 ; if not take 0

- Client type as private or public: for public clients take 1 ; for private take 0 
- Construction delivery system: for designbuild projects take 1 ; for others take 0

- Project type: for residential projects take 1; for others take 0 .

- Contractor PM's seniority: for number of years in the company 15 and more than 15 take 1 ; for less take 0

- Contractor tender manager's seniority: for number of years in the company 15 and more than 15 take 1 ; for less take 0

After building the initial data table, it was noticed that the number of years in the company was not a good indicator, as only 28 out of 82 cases had responsible parties with seniority greater or equal to 15 years. This contradicts the common notion that tender and PMs are mostly grey-haired, experienced professionals. The data was revisited to determine the persons' number of years' experience in the field, rather than their numbers years at the company. The corrected data table for the general contractor tender professionals now has 47 persons that meet or exceed the 15-year threshold.

The following conditions were not distinctive, and therefore were not used in the analysis. The first two were derived from the literature presented in Table 1 and the third was derived from case knowledge:

- Previous experience on a similar type of project: general contractor has wide range of experience in almost all types of projects (originated from literature)

- Technical capacity of the general contractor: general contractor has both human resources and equipment to realize all the projects given a bid (originated from literature)

- Project type as residential, office, hospital, hotel etc. (originated from case knowledge)

After making these corrections, the truth table based on binary codes was formed according to the thresholds given in Table 3. Certain contradictions were observed for cases having the same conditions but giving different results. This step is shown in Figure 2 as the "Internal validity test." In order to eliminate the contradictions in the truth table, the following methods are suggested by Rihoux and De Meur (2009:

1. Add conditions to the model. This should be done cautiously and in a theoretically justifiable way.

2. Remove one or more condition(s) from the model and replace it/them with (an)other condition(s).

3. Re-examine the cases in a more qualitative way to determine what differentiates the contradictory cases but has not been considered in the model.

4. Reconsider whether all cases are truly part of the same population.

The process is an iterative trial-and-error process and only the steps that had a positive will be mentioned here. First, two additional conditions were added to the analysis. They are relevant to the hypothesis that organizational repetition affects project outcome. Similar to the previous collaboration between the general contractor and client, previous collaborations have been investigated between architect and consultants to the projects chosen as cases. In cases where the architectural works and consultancy services are provided via partnerships and consortiums, the general contractor's PM was asked about the qualitative differentiation of the data used to identify previous collaboration between parties. The conditions added to the analysis were as follows:

- Previous collaboration between the general contractor and architect within the last 10 years: if it exists take 1 ; if not take 0

- Previous collaboration between the general contractor and consultant within the last 10 years: if it exists take 1 ; if not take 0 
As a result of the deeper qualitative investigation of the data, two cases were distinguished as different from the rest of the sample population. One of those cases was designed as a PPP project, which does not follow the ordinary tender process. The other contradictory case was part of a bigger project executed in phases, and thus it could not be counted as an independent project. sets were obtained. These were previous work experience between architect and general contractor in the last ten years for projects not planned to be delivered as design and build; and contractor PM seniority of 15 years or more for design and build projects. Each of the solutions had 0.40 coverage, with a total of $80 \%$ coverage together, representing satisfactory solution

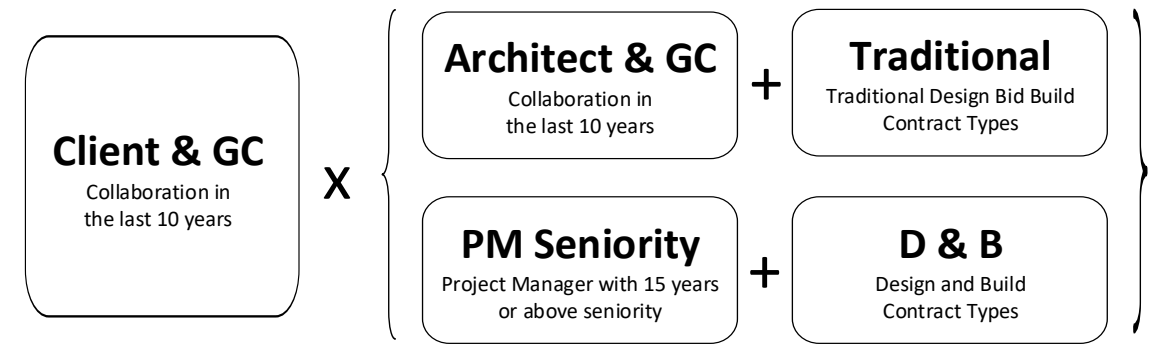

Figure 3. Simplified pathways leading to a successful bid, using Boolean algebra

Finally, after trial and error, the condition concerning the project type was found to be redundant, as it did not have an effect on building the truth table without contradictions. For the sake of simplicity, the condition 'Project type: for residential projects take 1 ; for others take 0 ,' was removed from the analysis. The final dichotomized table is presented in the Appendix in order to provide the reader with an overview of the data set.

\section{Phase 3 QCA Software analysis}

For the software analysis, the instructions from the QCA user guide by Ragin (2008) were followed. Software runs very rapidly, making it the simplest and fastest phase of the analysis once consistency is reached in the previous two phases. As mentioned, all the contradictions were eliminated in the previous phases. All observed cases were taken into consideration, giving a frequency of 1 .

In the results and discussion section that follows, only solutions with full consistency, based on the final contradiction-free truth table provided in the Appendix, will be presented.

\section{Results and Discussion}

As a result of the QCA software analysis, two different mechanisms in the form of two solution coverage according to the csQCA criterion of above 0.750 (Jordan et al., 2011; Thomas et al., 2014). To further reduce the complexity, the two pathways were simplified into a single solution set, as shown in Figure 3.

As seen in Figure 3, the necessary condition, previous work experience between client and general contractor in the last ten years, should be supported by other factors in order to achieve a successful bidding result. The solution set presented in Figure 3 is highly reliable, as it has coverage of $80 \%$, which is above the QCA acceptable limit (0.75), and a consistency of 1.0000. Moreover, the solution has a necessary (but not sufficient) condition: previous work experience between client and general contractor in the last ten years.

The frequency cut-off is 1.0000 , meaning that all cases were taken into consideration, even though the sample size (39 cases) was relatively large for conducting QCA analysis. The following solution space was found as a result of the standard analysis, with a solution consistency of 1.000 , since all contradictory cases were eliminated.

In order to interpret the solution sets obtained and to gain an in-depth understanding of the research results, case knowledge and experiences in the field were revisited. To extract the solution sets seen in 
Figure 3, previous work experience between client and general contractor was a necessary but not sufficient factor, as it existed in both solutions together with other factors. One can conclude that this is the most important factor, as it is present in both solution sets. Moreover, in the first solution path, previous work experience between architect and general contractor is decisive in cases with a project delivery system different from the designbuild system, such as the traditional design-bidbuild. The solution set supports the interviewees stating that in projects where the design-build delivery system was applied, the seniority level of the general contractor's PM plays a decisive role. In the design-build delivery system, the design task is expected to be delivered or coordinated by the general contractor alongside the execution of construction. Therefore, the experience of the PM plays an important role.

The factors not present in the solution are actually counterintuitive. Previous work experience between consultant and general contractor was expected to be an important factor; however, it is not present in the solution set. This might be because of the limited number of consultants undertaking the big projects included in the data set. The same consultant groups in Denmark mostly undertake the consultancy works of projects above a certain size.

Another factor absent in the solution set is client type, which describes whether the client is public or private. The absence of this factor may be explained by PM interviews conducted. According to the interviewees, due to the size of the projects, the private and public client organizations are similar to one another in terms of hierarchy and structural complexity. It is concluded that similar competitive bidding processes are run for private and public projects. Although some factors are not present in the solution set, it is important to note that all factors are considered together holistically to obtain a contradiction-free data set leading to the end solution.

It makes complete sense to have previous work experience with the architect in non-design-andbuild cases in the solution set. In traditional delivery systems, tasks are separated, meaning simply that the architect designs and the contractor builds. For design-and-build projects, on the other hand, the general contractor's PM plays an important role, as the design tasks are expected to be performed by the contractor along with the construction project execution. The performance of both design and build tasks under the same roof means more responsibility and risk for the general contractor. This special condition is therefore expected to be handled by a more senior PM.

Furthermore, in design-and-build cases, decisions must be taken in earlier project phases, whereas in the traditional design-bid-build contracts, many important decisions such as choice of contractor can be postponed. As seen in Figure 1. postponing decisions allows more time for important decisions to be made but adds to the uncertainty. According to the solution paths, the challenge of overcoming uncertainty in the design-and-build project delivery system must be handled by experienced PMs.

The results do not necessarily impose one project type over others, as there might be a project requirement that forces some decisions to be taken in later stages in order to maintain flexibility. However, mechanisms leading to successful tendering should be known when PMs are allocated to different types of projects.

Although the projects that contractors bid on depend on the current project portfolio, their technical and financial ability to execute the project, and the risk acceptance level, it might be beneficial for the bidder to be aware of the combinations of different factors that are more likely to result in particular outcomes. Finally, factors affecting the project outcomes are varied and it is debatable whether particular ones can be highlighted, since projects are arguably unique. However, looking at 39 projects of a similar size and scope over a 5-year time frame provides an opportunity to describe a pathway of factors working together to cause a particular tender result.

\section{Conclusions}

This paper set out to identify and present a mechanism that can enable successful tenders by general contractors. The two following combinations of factors that form pathways leading 
to particular project tender results, or more precisely, to won or lost bids (as seen from the bidder's perspective) were found. For design-bidbuild projects, previous work experience between client and general contractor, together with previous work experience between architect and general contractor while for design-build projects, previous work experience between client and general contractor, together with a senior PM's involvement in are the paths leading to the general contractor signing the contract.

As construction projects are typical examples of complex project-based work, companies operating in the construction sector must deal with the challenges of project-based organization. Due to the temporality of projects, the companies operating in the construction sector constantly need to win new projects in order to perform and survive.

The tender phase is the critical stage in the project life cycle in which many important decisions, such as choice of contractor and subcontractors are made, and uncertainty is the highest. This study adds the contractor's perspective to the picture rather than only the client's. The factors affecting the client's decision that are covered in literature, together with factors from case knowledge, have been researched, with the aim of identifying the combination of conditions that affect the bid results.

The factors investigated were previous work experience between client and general contractor, previous work experience between architect and general contractor, previous work experience between consultant and general contractor, the type of project delivery system, project type, seniority of general contractor's PM, and the seniority of the general contractor's tender manager.

The QCA method was used, as the method is able to work with midsize data sets (in this case, 39 projects) as well as deepen the research qualitatively by combining the benefits of topdown and bottom-up research strategies.

As a result of the QCA software analysis, two solution sets, both having 0.4 solution coverage, were found and are presented in Figure 3. They were then simplified into one solution set having 0.8 solution coverage. The frequency cut-off was set at 1, meaning that all observed cases represented in the solution set have been considered.

In this particular case, working with a previouslyknown customer appears to be important for contractors whose survival depends heavily on winning new contracts in order to continue performing in a project-based work environment. It is important to note that in two solution sets, previous work experience between client and general contractor appears to be a necessary condition that must be supported by other factors, depending on the project attributes.

Finally, it is important to note that the obtained results are very much context dependent. Similar analysis done on companies of a similar size operating in different geographies and contexts may give different results. Further case studies can be conducted with additional factors. For example, type of contract which one would intuitively think would play a role is not considered as a factor because in Danish context contracts are lump sum and other forms such as unit price or cost plus profit are rare. This can be added as a factor. More case studies following the same research design and data validation steps could be beneficial in order to draw more generalized conclusions.

\section{References}

Bagies, A. and Fortune, C. (2006) Bid/ no-bid decision modelling for construction projects. In: Boyd, D (Ed) Procs 22nd Annual ARCOM Conference, 4-6 September 2006, Birmingham, UK, Association of Researchers in Construction Management, 511-521.

Becker, M. (2004) Organizational routines: a review of the literature. Industrial and Corporate Change, 13(4), p.643-678.

Berg-Schlosser, D. and De Meur, G. (2009) Comparative Research Design: Case and variable selection. In Ragin \& Rihoux (Eds.), "Configurational Comparative Methods: QCA and related techniques" (pp. 19-32). London: Sage Publications.

Bernold, L. and AbouRizk, S. (2010) Managing Performance in Construction. John Wiley \& Sons. 
Freeman, M., \& Beale, P. (1992). Measuring project Success. Project Management Journal, 23 (1), 8-17.

Boudet, H., Jayasundera, D. and Davis, J. (2011). Drivers of Conflict in Developing Country Infrastructure Projects: Experience from the Water and Pipeline Sectors. Journal of Construction Engineering and Management, 137(7), 498-511.

Bower, D. (2003) Management of Procurement (1st ed.) Thomas Telford, London.

Chatterley, C., Javernick-Will, A., Linden, K.G., Alam, K., Bottinelli, L. and Venkatesh, M. (2014) A qualitative comparative analysis of well-managed school sanitation in Bangladesh. BMC public health, 14(1), 1 .

Cheng, E. W. and Li, H. (2004) Contractor selection using the analytic network process. Construction management and Economics, 22(10), 1021-1032.

Chinowsky, P. (2011) Engineering project organization: defining a line of inquiry and a path forward. Engineering Project Organization Journal, 1:1, 310, DOI: 10.1080/21573727.2010.549611

Cornick, T.C. and Mather, J. (1999) Construction project teams: making them work profitably. London, Thomas Telford.

Dewulf, G. and Kadefors, A. (2012) Collaboration in public construction-contractual incentives, partnering schemes and trust. Engineering Project Organization Journal, 2(4), 240-250.

Diekmann, J. (1981) Cost-plus contractor selection. Journal of the Technical Councils, ASCE, 107:13 25.

Fayek, A. (1998) Competitive bidding strategy model and software system for bid preparation. Journal of Construction Engineering and Management, 124(1), $1-10$.

Geraldi, J. and Adlbrecht, G. (2007) On faith, fact and interaction in projects. Project Management Journal, Vol. 38 No. 1, pp. 32-43.

Gersick, C. and Hackman R. (1990) Habitual routines in task-performing groups. Organisational Behaviour and Human Decision Processes, 47, 65-97.

Gross, M.E. and Garvin, M. (2011) Structuring PPP tollroad contracts to achieve public pricing objectives. Engineering Project Organization Journal, 1(2), 143-56.

Hatush, Z. and Skitmore, M. (1997) Criteria for contractor selection. Construction Management and Economics, 15:19 38.

Hatush, Z. and Skitmore, M. (1998) Contractor selection using multicriteria utility theory: an additive model. Building and Environment, 33(2 3): 105 115.

Homayouni, H., Dossick C.S. and Neff G. (2011) Construction Projects as Fuzzy-Sets: A Set Theoretic Approach to Analyzing the Role of Building Information Modeling in Higher Performance
Buildings. Working Paper Proceedings Engineering Project Organizations Conference.

Jordan, E., Gross, M., Javernick-Will, A.N. and Garvin, M. (2011) Use and misuse of qualitative comparative analysis. Construction Management and Economics, 29:11, 1159-1173.

Jordan, E., Javernick-Will, A. and Amadei, B. (2014) A qualitative comparative analysis of neighborhood recovery following Hurricane Katrina. International Journal of Disaster Resilience in the Built Environment, Vol. 5 Iss: 4, pp.391 - 412.

Kaminsky, J. and Javernick-Will, A. (2014).Theorizing the Internal Social Sustainability of Sanitation Organizations. Journal Construction Engineering Management, Vol.141 Iss:2 4014071, DOI: 10.1061/(ASCE)CO.1943-7862.0000933.

Kog, Y.C. and Loh P.K. (2012) Critical success factors for different components of construction projects. Journal of Construction Engineering and Management, 138(4), 520-528.

Langlois, R. (1992) Transaction-cost economics in real time. Industrial and Corporate Change, 1, 99-127.

Langlois, R. and Everett, M. (1994) What is evolutionary economics? in L.Magnusson (ed.), Evolutionary and Neo-Schumpeterian Approaches to Economics, pp. 11-48. Kluwer: Dordrecht.

Marshall, N. (2014) Thinking, saying and doing in collaborative projects: What can we learn from theories of practice? Engineering Project Organization Journal, 4:2-3, 107-122.

Mochtar, K. and Arditi, D. (2001) Pricing strategy in the US construction industry. Construction Management \& Economics, 19(4), 405-415.

Morris, P.W.G., (2013) Reconstructing project management reprised: a knowledge perspec-tive. Project Management Journal, 44 (5), 6-23.

Müller, R. and Turner, J.R. (2007) The Influence of Project Managers on Project Success Criteria and Project Success by Type of Project. European Management Journal, 25 (4), 289-309.

Nelson, R.R. (1994) Routines. in G. Hodgson, W. Samuels and M. Tool (eds), The Elgar Companion to Institutional and Evolutionary Economics, vol. 2, pp. 249-253. Edward Elgar: Aldershot.

Nieto-Morote, A.M. and Ruz-Vila, F. (2012) A fuzzy multi-criteria decision making model for construction contractor prequalification, Automation in Construction, 25 (2012) 8-19.

Nguyen, V. (1985) Tender evaluation by fuzzy sets. Journal of Construction Engineering and Management, ASCE, 111:231 243.

Ragin, C. (1987) The Comparative Method: Moving Beyond Qualitative and Quantitative Strategies. London, UK: University of California Press. 
The Engineering Project Organization Journal (October 2017) 7, 2

Ragin, C. (2008) User's Guide to Fuzzy-Set / Qualitative Comparative Analysis. Department of Sociology University of Arizona.

Rihoux, B. (2006) Qualitative Comparative Analysis (QCA) and related systematic comparative methods: recent advances and remaining challenges for social science research. International Sociology, 21(5), 679-706.

Rihoux, B. and De Meur, G. (2009) Crisp-Set Qualitative Comparative Analysis (csQCA). In C. Ragin \& Rihoux (Eds.), "Configurational Comparative Methods: Qualitative Comparative Analysis (QCA) and related techniques" (pp. 33-68). Sage Publications.

Thomas, J., O'Mara-Eves, A. and Brunton, G. (2014) Using qualitative comparative analysis (QCA) in systematic reviews of complex interventions: a worked example. Systematic Reviews, 3:67.

Tyre, M.J. and Orlikowski, W.J. (1996) The episodic process of learning by using. International Journal of Technology Management, 11, 790-798.

Winch, G., Usmani, A. and Edkins, A. (1998) Towards total project quality: a gap analysis approach. Construction Management and Economics, 16, 193207.

Yamasaki, S. and Rihoux, B. (2009) A commented review of applications, in Rihoux, Benoit. and Ragin, Charles (eds) Configurational Comparative Methods: Qualitative Comparative Analysis (QCA) and Related Techniques, Sage, Thousand Oaks, CA, pp. 123-46. 
The Engineering Project Organization Journal (October 2017) 7, 2

\section{APPENDIX}

The final dichotomized table prior to the analyses

Project

Conditions

Outcomes

\begin{tabular}{|c|c|c|c|c|c|c|c|c|}
\hline $\begin{array}{l}\text { Project } \\
\text { case id }\end{array}$ & $\begin{array}{l}\text { GC \& } \\
\text { Client }\end{array}$ & $\begin{array}{c}\text { GC \& } \\
\text { Architect }\end{array}$ & $\begin{array}{c}\text { GC \& } \\
\text { Consultant }\end{array}$ & $\begin{array}{l}\text { Client } \\
\text { Type }\end{array}$ & $\begin{array}{l}\text { Delivery } \\
\text { System }\end{array}$ & $\begin{array}{c}\text { PM } \\
\text { Seniority }\end{array}$ & $\begin{array}{c}\text { Tender } \\
\text { Responsible } \\
\text { Seniority }\end{array}$ & $\begin{array}{l}\text { Tender } \\
\text { Result }\end{array}$ \\
\hline 1 & 1 & 1 & 1 & 0 & 1 & 1 & 1 & 1 \\
\hline 2 & 1 & 1 & 1 & 0 & 1 & 1 & 0 & 1 \\
\hline 3 & 1 & 1 & 1 & 0 & 1 & 1 & 0 & 1 \\
\hline 4 & 1 & 1 & 1 & 0 & 0 & 0 & 1 & 1 \\
\hline 5 & 1 & 1 & 1 & 1 & 1 & 1 & 1 & 1 \\
\hline 6 & 1 & 1 & 1 & 0 & 1 & 1 & 0 & 1 \\
\hline 7 & 0 & 0 & 1 & 1 & 1 & 1 & 0 & 1 \\
\hline 8 & 1 & 0 & 1 & 0 & 1 & 1 & 1 & 1 \\
\hline 9 & 1 & 1 & 0 & 0 & 0 & 1 & 0 & 1 \\
\hline 10 & 1 & 1 & 1 & 0 & 0 & 1 & 1 & 1 \\
\hline 11 & 1 & 1 & 1 & 1 & 0 & 1 & 1 & 1 \\
\hline 12 & 1 & 1 & 1 & 1 & 0 & 1 & 1 & 1 \\
\hline 13 & 1 & 1 & 1 & 0 & 0 & 1 & 0 & 1 \\
\hline 14 & 1 & 0 & 1 & 0 & 1 & 1 & 0 & 1 \\
\hline 15 & 1 & 1 & 1 & 1 & 1 & 1 & 1 & 1 \\
\hline 16 & 0 & 0 & 1 & 0 & 1 & 0 & 0 & 1 \\
\hline 17 & 0 & 0 & 1 & 1 & 0 & 0 & 0 & 1 \\
\hline 18 & 1 & 1 & 1 & 1 & 0 & 1 & 1 & 1 \\
\hline 19 & 1 & 0 & 0 & 1 & 1 & 0 & 0 & 1 \\
\hline 20 & 1 & 1 & 1 & 1 & 0 & 1 & 1 & 1 \\
\hline 21 & 1 & 0 & 0 & 0 & 0 & 1 & 1 & 0 \\
\hline 22 & 0 & 0 & 1 & 0 & 1 & 1 & 0 & 0 \\
\hline 23 & 1 & 0 & 1 & 0 & 1 & 0 & 1 & 0 \\
\hline 24 & 0 & 0 & 1 & 0 & 1 & 1 & 0 & 0 \\
\hline 25 & 1 & 1 & 0 & 0 & 1 & 0 & 1 & 0 \\
\hline 26 & 0 & 0 & 0 & 0 & 1 & 0 & 0 & 0 \\
\hline 27 & 1 & 1 & 0 & 0 & 1 & 0 & 0 & 0 \\
\hline 28 & 0 & 1 & 1 & 0 & 1 & 1 & 1 & 0 \\
\hline 29 & 0 & 1 & 0 & 0 & 0 & 0 & 1 & 0 \\
\hline 30 & 1 & 0 & 0 & 0 & 1 & 0 & 1 & 0 \\
\hline 31 & 0 & 0 & 0 & 0 & 0 & 0 & 0 & 0 \\
\hline 32 & 1 & 1 & 1 & 0 & 1 & 0 & 0 & 0 \\
\hline 33 & 0 & 0 & 0 & 0 & 1 & 1 & 0 & 0 \\
\hline 34 & 1 & 0 & 1 & 0 & 0 & 1 & 0 & 0 \\
\hline 35 & 1 & 0 & 1 & 1 & 0 & 1 & 1 & 0 \\
\hline 36 & 0 & 0 & 1 & 0 & 1 & 1 & 1 & 0 \\
\hline 37 & 1 & 0 & 1 & 0 & 1 & 0 & 0 & 0 \\
\hline 38 & 0 & 0 & 0 & 0 & 1 & 0 & 1 & 0 \\
\hline 39 & 1 & 1 & 1 & 1 & 1 & 0 & 0 & 0 \\
\hline
\end{tabular}

